IZA DP No. 10232

Understanding the Effects of Homeownership and Regional Unemployment Levels on Migration during the Economic Crisis in Spain

Isabel Palomares-Linares

Maarten van Ham

September 2016 


\title{
Understanding the Effects of Homeownership and Regional Unemployment Levels on Migration during the Economic Crisis in Spain
}

\author{
Isabel Palomares-Linares \\ University of Granada
}

Maarten van Ham

Delft University of Technology

and IZA

\section{Discussion Paper No. 10232 \\ September 2016}

\author{
IZA \\ P.O. Box 7240 \\ 53072 Bonn \\ Germany \\ Phone: +49-228-3894-0 \\ Fax: +49-228-3894-180 \\ E-mail: iza@iza.org
}

\begin{abstract}
Any opinions expressed here are those of the author(s) and not those of IZA. Research published in this series may include views on policy, but the institute itself takes no institutional policy positions. The IZA research network is committed to the IZA Guiding Principles of Research Integrity.

The Institute for the Study of Labor (IZA) in Bonn is a local and virtual international research center and a place of communication between science, politics and business. IZA is an independent nonprofit organization supported by Deutsche Post Foundation. The center is associated with the University of Bonn and offers a stimulating research environment through its international network, workshops and conferences, data service, project support, research visits and doctoral program. IZA engages in (i) original and internationally competitive research in all fields of labor economics, (ii) development of policy concepts, and (iii) dissemination of research results and concepts to the interested public.
\end{abstract}

IZA Discussion Papers often represent preliminary work and are circulated to encourage discussion. Citation of such a paper should account for its provisional character. A revised version may be available directly from the author. 
IZA Discussion Paper No. 10232

September 2016

\section{ABSTRACT}

\section{Understanding the Effects of Homeownership and Regional Unemployment Levels on Migration during the Economic Crisis in Spain}

The Spanish labour market is characterised by high levels of unemployment, which have increased during the global economic crisis. Spain is also a country which is characterised by a very high percentage of homeownership, with more than $83 \%$ of households being owneroccupiers. Both regional levels of unemployment and homeownership are known to be important factors influencing the spatial mobility decisions of households, but little is known about how these factors influenced mobility during the recent economic crisis. This paper uses rich individual level microdata from the last two Spanish censuses (2001 and 2011) to study the effect of homeownership and regional unemployment levels on both short and long distance mobility. Our finding suggest that the role, influence and interconnection of unemployment and homeownership in mobility decision have changed in the last decade.

JEL Classification: J21, J61, J64

Keywords: short distance mobility, long distance mobility, economic recession, unemployment rate, homeownership

Corresponding author:

Isabel Palomares-Linares

Department of Sociology

University of Granada

C/ Rector López Argueta s/n

18071 Granada

Spain

E-mail: ipalomares@ugr.es 


\section{Introduction}

"men do not flow from places of poor to places of good opportunity with the ease of water" (Blau and Duncan, 1967: 243).

Neoclassical economic theory predicts that people move from regions with high levels of unemployment to regions with low levels of unemployment Courchene, 1970; Greenwood, 1985; Pissarides and McMaster, 1990). There is a large literature investigating the role of regional labour market conditions in understanding the spatial mobility patterns (both short distance residential mobility and long distance migration) of workers (Harris and Todaro, 1970; Fields, 1976; Cleave and Cordey-Hayes, 1977; Bartel, 1978; Beyers, 1980; Shields and Shields, 1989). This literature often takes into account both characteristics of regions of origin and destination, and shows evidence that people are indeed more likely to leave regions with high unemployment levels and move to more dynamic labour markets.

However, there is also ample literature showing that the relationship between regional labour market characteristics and the spatial mobility decisions of households is complex. As already observed by Blau and Duncan (1967), there are both micro-level restrictions and macrolevel constraints, which stop households from responding to labour market opportunities elsewhere (see also van Ham et al., 2001). A range of factors is taken into account in a household's cost-benefit analysis of a potential move, including, for example, labour and housing market conditions (Bonnar, 1979; Davies and Clark, 2006; Coulson and Fisher, 2002), commuting costs (Van Ham and Hooimeijer, 2009), local amenities (Chen and Rosenthal, 2008), and local ties to friends and family (Cooke, 2008; Bähr and Abraham, 2016). Possibly one of the most important factors influencing spatial mobility decisions is homeownership. Homeowners are often found to be less likely to move than renters because of both economic and non-economic factors. Economic factors include the high costs associated with selling and buying a house (Mulder and Wagner, 1998; Quigley, 2002), and long term commitments to mortgage lenders (García-Lamarca and Kaika, 2016). Homeowners also invest more in their place of residence than renters (DiPasquale and Glaeser, 1999), and the probability to move elsewhere decreases with higher levels of 'local specific capital' (DaVanzo, 1981b; Mulder and Malmberg, 2014). Instead of moving home to accept new job opportunities, homeowners are more likely to accept a long commute to work (Van Ham and Hooimeijer, 2009).

This paper aims to better understand both short and long distance mobility of households in Spain in the 2001-2011 period. The Spanish labour market is characterised by very large regional differences in unemployment levels and these regional differences have widened during the global economic crisis which started in 2008. Spain is also a country which is characterised by a very high percentage of homeownership, with more than $83 \%$ of households being owneroccupiers (INE, 2016). This 'homeownership culture' (Leal, 2010) has been identified as a major factor in understanding persistently low spatial mobility rates (over both long and short distances) in the last decades (Cabré and Módenes, 2004). Spanish households often live long periods in the same dwelling, sometimes from the beginning of their housing careers and in the same (or close to) municipalities where they were born (Holdsworth and Solda, 2002; Puga, 2004).

The effects of home ownership and regional unemployment levels on spatial mobility decisions are not independent from space and time, from where and when decisions are made (Creswell, 2006). In Spain, moving behaviour in the 2001-2006 period of fast economy growth is likely to be different from behaviour in the 2008-2013 period of hard economic recession. Although several studies have investigated the effect of the global economic crisis on the housing and occupational status of households in Spain (Módenes and López-Colás, 2014; Moreno, 2016), we know little about the effect of the crisis on both short and long distance mobility patterns. Given the high and increasing levels of unemployment in Spain (with over 60\% unemployment in the south of Spain in 2011), and very high homeownership rates, research investigating the effects of homeownership and regional levels of unemployment on migration is very timely. 
This paper uses rich individual level microdata from the last two Spanish censuses (2001 and 2011) to study the effect of homeownership and regional unemployment levels on both short and long distance mobility. The 2001 census took place during a period of economic boom, and the 2011 census took place during the global economic crisis. We use a temporal-spatial perspective to investigate the mobility behaviour of households, and this study aims to better understand the role of, and interactions between, homeownership and structural unemployment in Spain. Since people don't flow with the easy of water, we try to better understand both "against the tide" and "going with the flow" trajectories.

\section{Literature review}

\section{Labour markets, regional unemployment and mobility}

There is a large literature on the relationship between labour markets and the spatial mobility of workers (Harris and Todaro, 1970; Fields, 1976; Cleave and Cordey-Hayes, 1977; Bartel, 1978; Beyers, 1980; Shields and Shields, 1989). Both studies which investigate migration flows (Markow models -Ginsberg, 1971-; Gravity models - Clark and Ballard, 1980; Crozet, 2004), and studies which investigate individual behavior (Alperovich et al., 1977; DaVanzo, 1981a; Ballard and Clark, 1981), show strong evidence that generally speaking people move in the direction of employment opportunities as places of opportunity benefit individual labour careers and social mobility. Van Ham et al. (2001) stated that in this respect spatial mobility can be understood as an instrument which helps workers to benefit from employment opportunities elsewhere. Migration is also instrumental in leaving situations of economic dependency in more vulnerable labour markets (unemployment: Antolin and Bover, 1993; leaving the parental home: Jones, 1999; Garasky, 2002).

The regional unemployment rate is the most important indicator of labour market performance. Classical economic theory of internal migration predicts that people are most likely to leave regions with high levels of unemployment as these regions offer few opportunities to (re)enter the labour market and experience upward occupational mobility (Courchene, 1970; Greenwood, 1985; Pissarides and McMaster, 1990). There is ample empirical evidence for this relationship in a range of countries (Greenwood, 1975; Grant and Vanderkamp, 1980; Liu and Shen, 2013) and although the leading perspective is economic/econometric, the logic behind the behaviour of people can also be understood from a sociological perspective: people move spatially as a way to move socially. However, the assumption that high regional unemployment levels lead to higher levels of mobility is also criticized (see Clark, 1982 for an extended overview). Several authors have pointed at methodological issues as studies of migration flows and micro behavioural studies sometimes lead to contradictory outcomes (Dahlberg and Holmlund, 1978; McCormick, 1997). Others have argued that other measures than regional (labour) market performance may be more suitable to understand migration behaviour (Fields, 1976; Elhorst, 2003). There is now a growing literature highlighting the complexity of the relationship between labour market characteristics and labour careers and migration (Dahl et al., 2010; Morrison and Clark, 2011; Van Ham et al., 2012).

As explained by DaVanzo (1981a), people move home with the expectation to do better after the move compared to before the move. But in assessing the benefits of a move, also the costs are taken into account, not only the economic costs, but also the non-economic costs. People might decide to stay in a region with high unemployment levels because the overall quality of life. The amenity perspective (Graves, 1976; Chen and Rosenthal, 2008) has pointed out that quality of life, regional specific characteristics such as the climate (Rappaport, 2007) or the social/public services available (Graves, 1976), or the low costs of living (Cebula, 1979) can all compensate for a poorly performing labour market. Also the geography of social capital plays a role regarding the attractiveness of a place: social and family ties have been mentioned as important reasons to stay put (Cooke, 2008; Mulder and Malmberg, 2014; Niedomysl and Clark, 
2014; Bähr and Abraham, 2016). These factors have been suggested to (at least partly) explain the low mobility in the southern Spanish region of Andalucía. With the highest unemployment rate of the country this region receives more people than there are people leaving (Artal et al., 2015). This all does not mean that regional disadvantage is not connected with the likelihood to move to better places. Also DaVanzo (1978) and Blau and Duncan (1967) found a relationship between living in economically disadvantaged regions and the propensity to move. Summarising the above it can be concluded that the relationship between regional unemployment and migration is not linear and is moderated by social and spatial factors, and that this relationship should be investigated further in different contexts and periods.

\section{Residential ties, homeownership and immobility}

When a household makes a cost-benefit analysis of a potential move, a range of factors is taken into account. Labour and housing market conditions (Davies and Clark, 2006; Coulson and Fisher, 2002), local amenities (Chen and Rosenthal, 2008), and local ties to friends and family (Cooke, 2008; Bähr and Abraham, 2016) are all playing a role. But one of the factors most associated to immobility is homeownership (Fisher and Malmberg, 2001; Mulder, 2006). With regard to long distance mobility, being a homeowner can reduce the benefits of accepting a job elsewhere. Van Ham and Hooimeijer (2009) found for the Netherlands that homeowners are more likely to accept a long commute than to migrate. Homeownership was also found to reduce the likelihood of short distance mobility (Clark and Dieleman, 1996). The role of homeownership in mobility decisions varies by household status (Mulder and Wagner, 1998; Holland, 2012), the state of the local housing market (Helderman et al., 2004; Davies and Clark, 2006), and the political context (Ronald, 2008; Leal, 2010; Kemeny, 2001), but in general, homeowners move less than renters.

Both the economic and non-economic costs of moving are higher for homeowners than for renters. The main economic arguments refer to the material costs of moving, which include all the costs associated with selling and buying a home, such as notarial costs and estate agent fees, but also costs related to re-decorating a new dwelling (Mulder and Wagner, 1998; Quigley, 2002). In the short term, such immediate costs associated with moving home, make homeowners less likely to move soon again than renters. Also long term commitments to mortgage lenders have a negative effect on mobility (, especially in areas where house prices have dropped (Cabre and Módenes, 2004), and especially for young adults who have entered the housing market as first-time buyers in the period of economic growth before the crisis (Módenes et al., 2013; Palomares, 2014). Homeowners also socially invest more in their place of residence than renters (DiPasquale and Glaeser, 1999), and they accumulate more local social capital (DaVanzo, 1981b), which reduces the likelihood of moving (Fors and Lennartsson, 2008). Also having local family ties (Mulder and Cooke, 2009; Mulder and Malmberg, 2014), local knowledge (Fisher and Malmberg, 2001), and a dense social network (Dawkins, 2006) are factors related to homeownership which make people relatively immobile. Homeownership implies a certain residential compromise in social terms compared to renting, as both housing tenures are associated to different periods in the life course (Mulder, 2006), and different life styles (Aramburu, 2015). The role of homeownership in migration is also likely to differ between social classes as lower social classes have less financial resources, less economic security, and might depend more on local family support (Litwak and Szelenyi, 1969; Campbell et al., 1986). Hence, the meaning of homeownership and its immobilizing powers are likely to vary by household composition and resources.

\section{Mobility, regional unemployment and homeownership in the current Spanish context}

Compared with other European countries, mobility rates in Spain have been low in the last decades (Módenes, 2004; Módenes, 2007). Even so, both internal migration and residential mobility rates have been increasing from the 1990s, reaching a historically high level in the period between 2000 and 2008 (Artal et al., 2015). This increase of mobility is associated with strong economic growth and expansion of urban regions all over the Spanish territory with both temporal 
and geographic variations regarding the direction of migration flows (Coll and Stillwell, 1999). However, despite the increase in mobility, close to $95 \%$ of the population had not moved in the last censuses compared to the previous year (see Table 2 in the Results section); this implies that Spain is a country of stayers. There are three main factors influencing the relative immobility of the Spanish population. First, the labour market is geographically divided into inflexible submarkets such as tourism, agriculture, and industry (Dolado et al., 1986; Jimeno and Bentonilla, 1998). Second, there is a strong effect of local family networks and attachment to the region of birth (Reher, 1998; Puga, 2004). And third, and maybe most important, the Spanish housing market is characterized by a very strong homeownership culture (Leal, 2010; Pareja-Eastaway, 2007). Since the first Spanish minister of housing said "let's make a country of homeowners, not proletarians" (García-Lamarca and Kaika, 2016), political actions and institutional factors have favored homeownership above renting (Leal, 2010; Modenes at al., 2013). In Spain becoming a homeowner is often the first step on the housing ladder as part of the trajectory of autonomy and leaving the parental home (Holdsworth and Solda, 2002). In 2011, more than 83\% of the population was a homeowner.

We know from the literature that the 2008 economic crisis had a major impact on housing careers of households and on their mobility behaviour (Módenes and López-Colás, 2014; Palomera, 2014). But up to now there has been no detailed study on the relationships between homeownership, regional unemployment levels and residential mobility and migration, and the interconnections between these factors. The economic crisis may not only have affected mobility itself, but it could also have changed the effects of regional unemployment levels, or homeownership, on mobility. We can summarize our arguments for this study as follows:

Regional unemployment rates and long distance mobility. The Spanish literature shows contradictory results regarding the role of regional unemployment and migration (Bentolila and Dolado, 1990; Antolín and Bover, 1993). During the crisis unemployment levels have increased everywhere, but especially in some regions such as Andalusia and Extremadura. So although in the past the relationship between unemployment and migration was not clear, the impossibility for many to find a job might lead them to look for opportunities elsewhere. On the other hand, as Morrison and Clark (2011) point out, the structural changes in the national labour market could be seen as a reason to stay put as job opportunities are perceived to be poor everywhere.

Regional unemployment and short distance mobility. Although unemployment rates have been included as an explanation for long distance mobility, there is less evidence with regard to its role in understanding short distance mobility. Regional characteristics may not be so important to explain local moves, but a poor local labour market could lead to immobility for two reasons. First, a high regional unemployment level usually means less opportunities to find a permanent job, but also increases the risk of unemployment (Jimeno and Bentonilla, 1998). As a result people in such regions might be less likely to move locally because they are avoiding financial risks. Second, a distressed local context can also influence the collective imaginary, producing negative social discourses and fears that are shared and reproduced swiftly and lead to even less mobility (Conde, 2004).

Homeownership and long/short distance mobility. Spanish researchers have explained the low residential mobility rates in Spain as a consequence of the preference to own a house (Leal, 2004). But they also pointed out that the increase in migration in the recent past (1996-2008) is a consequence of the decreasing effects of homeownership on residential moves (Módenes and López-Colás, 2014). It was found that onward moves, from ownership to ownership, have become more and more common as the dynamic Spanish housing market in the economic growth period made it possible to invest in a new dwelling while selling the old dwelling quickly. Helderman et al. (2004) pointed out that the meaning and utility of homeownership change through the economic cycles of boom and bust, where during an economic crisis homeownership is mainly a factor that causes people to stay put, both over short and long distances. In the Spanish context of the economic crisis, the security role of homeownership (Hiscock et al., 2001) could be a major factor in explaining immobility. Due to the social differences in need/support of social/family and residential resources (Campbel et al., 1986), homeownership could be a major factor in explaining 
immobility in disadvantaged regions where the economic and labour market consequences of the recession have impacted hardest.

\section{Data and methods}

\section{Data and sample}

For our analysis, we used the individual level microdata of two last Spanish Censuses conducted in 2001 and 2011. The 2001 microdata is a 5\% sample of the whole population in 2001 and was obtained by simple random sampling methods. The 2011 microdata is a $10 \%$ sample of the whole population in 2011 and was obtained using a sampling methods with weights based on the size of localities. With increasing population, the sample size decreased (for more detail see: Census Project INE, 2011). As a result of this sampling method, the rural population is overrepresented if the weights are not applied. Therefore, we calculated aggregated rates and we ran our models using proportional weights as provided by the Spanish Institute of Statistics.

Starting with the two census micro datasets we have made a number of selections. We have removed: (i) individuals who are 17 years old or younger, and those in between 18-28 years old but still living with their parents as they do not form independent households who decide on moving behaviour; (ii) immigrants who moved to Spain in the year before the census as they were not at risk of moving within Spain compared to one year ago; (iii) residents of Ceuta y Melilla, which is a Spanish enclave in Morocco. After these selections, our final sample consists of 1.364.960 inhabitants in 2001 and 2.953.774 inhabitants in 2011.

\section{Variables}

The dependent variable in this study measures both short and long distance mobility. We determined whether a move took place in the year before the census by using two questions: Where was your last place of residence? and When did you move to your current dwelling? Based on these questions we were able to determine both origin and destination of movers in the year before each census. It is important to note that the way in which the arrival date to the current dwelling was registered is different in the 2001 and 2011 census. In the 2001 Census, every person living in the same household was assigned the same arrival date: the year of the first person who inhabited the dwelling. In 2011, the arrival date is not a household variable but an individual level variable. Although using individual level information is the most accurate way to register moves, we have recoded this information using the 2001 method for comparability reasons.

For the logit regression models, we constructed two dummy variables. The short-distance dummy mobility is coded 0 for stayers, and 1 for movers within the same municipality (excluding those who moved over long distance). The long-distance dummy is coded 0 for stayers and 1 for those who moved from a different province (excluding those who moved over a short distance) (see Table 1 for totals). We have separated short and long distance mobility because the underlying mechanisms are very different (Courgeau, 1988). The main independent variable in our models is the regional unemployment level. For both our short and long distance models we have used the provincial unemployment rates one year before each census (2000 for the 2001 Census, and 2010 for the 2011 Census). Using lagged regional unemployment information is necessary to avoid endogeneity issues and to obtain correct estimates based on the characteristics of the place of residence before the last move. Because we needed lagged information we could not use the census, and obtained data from the Encuesta de Población Activa ${ }^{l}$ (EPA). For both short and long distance mobility models, the regional unemployment level was centered using the national mean in 2000 or 2010 . We have used provincial unemployment data because these are proxies for functional regional labour markets or metropolitan areas. Spanish metropolitan regions have developed strongly in the last two decades and almost every province experienced

\footnotetext{
${ }^{1}$ Rotational Panel Survey conducted by the Spanish Institute of Statistics four times per year, using a sample of 65.000 households. We use the yearly average unemployment rate.
} 
some level of metropolitan expansion (Feria, 2010). Unfortunately our data did not allow us to construct metropolitan areas as municipality codes are not available for municipalities with less than 20.000 inhabitants.

The second main independent variable in our models is homeownership. The category of homeowners consists of outright owners (who fully own their dwelling), and homeowners with a mortgage. The other two housing tenure categories are renters and other (not owning or renting). As with all studies using cross-sectional census data, information on many variables, including homeownership, is based on the place of residence at the time of the census. Although census questionnaires often include questions on the last place of residence, not other information on this last place of residence is collected. This artefact of census data implies that the models of mobility are slightly biased with regard to the effect of housing tenure on mobility. Some of the homeowners after the move were renters before their move and the other way around. Fortunately we know from the literature that most moves occur within the same tenure, but it is important to keep this shortcoming of the data in mind when interpreting the results of the regression analysis.

Other variables included in the models as control variables are briefly described in Table 1. We checked for multicolineality problems using the VIF Test and specification problems of independent variables. The results of these tests are available from the authors upon request.

$* * *$ Table 1 around here $* * *$

\section{Analytical strategy}

We first provide descriptive analyses of short and long distance mobility by Census year and province. To further investigate the effects of the regional unemployment rate and homeownership we ran separate logistic regression models for both types of mobility. With individuals records of both Censuses pooled into one database, we ran three models. In the first model we included all our independent variables. In the second model we included Census year as a dummy $(0=2001 / 1=2011)$ to investigate changes in mobility over time. To further investigate the direction and intensity of changes, we included several interaction terms with census year in the third model: (i) Census year and unemployment level at origin and (ii) Census year and housing tenure at the year of the census. To better understand the effects of the interactions between homeownership, unemployment level and Census year on short and long distance mobility, we presented the average marginal effect (AME's) of homeowners (ref: renters) for the five unemployment rates quintiles. As homeownership is an inmobility factor, the AME's have been calculated over the probability to stay. We calculated AME's for 2001 and 2011 and compared the results as a way to correctly compare cross-sectional data (Mood, 2010).

For each model we provide measures of the model fit and we have checked the consistency of the models calculating coefficients as well as odd ratios (models with OR not shown but they can be obtained from the authors). Because the regional unemployment variable is measured at the level of provinces, we have used the cluster option in Stata so the standard errors are corrected. Hence, we allow for intragroup correlation and control for over/under estimating probabilities of provincial indexes.

Using provinces categorized by their unemployment level quintiles, we also calculated long distance mobility matrixes between quintiles in 2001 and 2011. For constructing these matrices we have only used interprovincial movers. For the analyses of the matrices we have used two common measures used in income and social mobility studies but rarely used for the study of socio-spatial mobility: Shorrocks Index of mobility rigidity (1978), based on the analysis of the matrix diagonal. We also used Bartholomew's Index (1973) to analyse movements between quintiles (moves up and down). The relative changes in indexes between the 2011 and 2001 matrices are useful to better understand socio-spatial dynamics and changes. 


\section{Results}

Changes in homeownership, unemployment levels and mobility between 2001 and 2011

In the last few decades, the Spanish housing market has been described as having a strong "ownership culture" (Leal, 2010; Aramburu, 2015), due to the strong role of homeownership as a way to enter the housing market (Cabré and Módenes; 2004) and the tendency of households to move between owner occupied dwellings (Módenes and López-Colás, 2014). Between 2001 and 2011, homeownership remained the tenure of choice for most households and in all regions (Figure 1). In 2011 the percentage of homeownership was over $72 \%$ in all provinces and still growing in many of them (although only slightly). The geographical variation in home ownership as shown in Figure 1 is also pointing at a relationship between metropolitan development, immigration rates and changes in the Spanish housing market. Although the Spanish rental market is still small, recent studies are showing evidence of an increasing role of the rental market in Spain (Módenes and López-Colás, 2014). Renting is especially popular with mobile groups such as young professionals, university students and immigrants from abroad. Thus, metropolitan areas, which have been receiving a high inflow of these groups during the first decade of the century have experienced a growing importance of the rental market.

Between 2001 and 2011 in almost all Spanish provinces unemployment levels have risen dramatically as a consequence of the economic recession. The underlying mechanisms are very similar in all provinces: rising unemployment levels in the construction sector; the entering of a large cohort of young people looking for work with limited vacancies; and the inflexibility of Spanish labour market system. The map in Figure 1 shows that despite overall increases in unemployment, the geographical distribution of vulnerable labour markets is clearly reproducing the historical differences between provinces and regions. The southern Spanish regions of Andalucía and Extremadura have been much harder hit by the economic crisis than other regions as their labour markets already underperformed in 2001 which was a period of economic boom.

$$
\text { *** Figure } 1 \text { around here*** }
$$

Table 2 gives more information on mobility rates by different types of mobility in both census years. In the 2011 period of economic recession the mobility rates are dramatically lower compared with 2001 (from 4, 95 to 2,61\% of the population in our study); mobility has almost halved in the study period. There have also been important changes in the types of mobility. In 2011 all types of mobility have dropped compared to 2001, but the largest drop can be seen for mobility between provinces: the interprovincial mobility rate in 2011 is $79 \%$ lower than in 2001 . During the economic crisis, people have largely remained in place, or at least stayed close to where they lived before.

$$
\text { *** Table } 2 \text { around here*** }
$$

Figure 2 shows the changes in (im)mobility between 2001 and 2011 by provinces. The figure shows that there is an increase in stayers almost everywhere, and in some provinces a small increase in mobility within municipalities. But the general trend is of declining mobility rates within and between provinces. The overall drop in mobility rates shows that there are underlying general mechanisms related to the economic crisis. But the variation between provinces show that these regional differences are rooted in historical and cultural differences between provinces. The southern provinces where traditionally unemployment is highest, also show the greatest drop in all types of mobility, suggesting longer term economical vulnerability in this part of Spain.

*** Figure 2 around here $* * *$ 


\section{Models of short distance mobility}

To get more insight into the role of homeownership and regional levels of unemployment we have used logit models to model the probability that people moved over short distance in the year before the census (see Table 3 ). Although aggregate short distance mobility rates have changed the least between 2001 and 2011 (see Table 2), we still find some interesting patterns in the analyses of microdata. In model 1 we find a strong relationship between housing tenure and short distance mobility: as expected, homeowners are much less likely to move over short distance than renters. We find a small positive effect of regional unemployment levels on short distance mobility; with increasing unemployment levels there is also an increase in short distance mobility, although the effect is hardly significant. The census dummy shows that in 2011 the probability to move over short distance was lower than in 2001. This shows important period effects on short distance mobility, which are related to the economic crisis.

Model 1 further includes a range of control variables, many which do not have a significant effect on mobility. We find a strong effect of age and household composition on mobility. With age mobility decreases, and families with children are less likely to move than couples. We also find that the unemployed and those who are inactive (those who are economically dependent) are less likely to move than those with a paid job. The results show that socio-economic status and region are not good predictors of short distance mobility. This is not surprising as in the Spanish context social class and geography have not shown marked differences in short distance mobility during the last decades (Cabré and Módenes, 2004). Finally we find that with increasing housing prices the probability to move over short distances decreases. In summary, short distance mobility is more connected to life course variables and housing market variables than to labour career variables.

In model 2 we have added several interaction terms. Adding these interactions improves the model fit significantly and clearly shows how much the effects of our main variables of interest have changed between 2001 and 2011. The interaction effect between census year and homeownership shows that in 2011 homeowners are much less likely to move over short distance than homeowners in 2001. This can be interpreted as a direct effect of the crisis where in 2011 the economy was much less stable than in 2001 and consumers were avoiding risk taking. Interestingly, the main effect of homeownership is much smaller after adding the interaction effect. This implies that the difference in short distance mobility rates in 2001 is much smaller between homeowners and renters than in 2011. As Módenes and López-Colás (2014) or Leal (2010) pointed out, in a period of economic growth and housing market bubble, the homeownership culture did not reduce, but increase the economic growth because homeowners were moving. But, the interaction is clearly showing that during an economic recession home ownership is much more associated with staying put.

In model 2 the main effect of regional unemployment on short distance mobility is still positive, in 2001 living in a more economically vulnerable province was associated with a higher probability to move. The interaction effect between unemployment rate and census year is negative. This means that in 2011 a higher unemployment rate had a negative effect on short distance mobility. So in 2011 living in a disadvantaged area is associated with a lower probability to move over a short distance. Again this points at an effect of the crisis where people are less likely to take the risk of moving locally in those regions with higher levels of unemployment. So unemployment levels are mainly relevant to understand temporal differences in short distance mobility, showing that structural regional vulnerability impacts the likelihood to move, reducing expectations and desires of climbing the housing ladder.

$$
* * * \text { Table } 3 \text { around here }{ }^{* * *}
$$

\section{Models of long distance mobility}

Table 4 shows logit models of the probability of moving over long distance. The effects of some of the main and control variables are different compared to the models of short distance mobility, showing that there are different mechanisms underlying decisions to move inside the same life 
space (short distance) or to move to another region. Model 3 shows that homeowners are much less likely to move over long distance than renters, which is as expected and associated with the higher costs (both monetary and non-monetary) of moving for homeowners compared to renters. The effect of the provincial unemployment rate is not significant in this model of long distance mobility. The effect of the census year dummy is large and negative (even larger than the effect of homeownership) showing that in 2011 the probability to move over long distance was much lower than in 2001.

Model 4 again includes various interaction effects with census year. We find that homeowners are much less likely to move over longer distances in 2011 compared to 2001, while the main effects of homeownership and census year hold. We did not find an interaction effect between census year and regional unemployment rate. In none of the long distance mobility models did we find an effect of unemployment rates on migration decisions. While we know from Blau and Duncan (1967) than men do not flow with the ease of water, it is quite striking to see that even high levels of unemployment do not affect long distance mobility. This might be explained by the geographical distribution of non-skilled and skilled labour markets (Dolado et al, 1986), or the fact that some economically vulnerable regions can still be attractive to live in (amenities), but cultural and social factors may also play a role. The Spanish population is likely to stay close to family networks (Reher, 1998), a mechanisms which is more relevant for the lower social classes. In times of economic crisis and increasing regional economic and social vulnerability, living close to social (family) networks may outweigh the benefits of moving over longer distance to a region with more employment opportunities.

The control variables for age show that with increasing age people are less likely to move over longer distances. We also find that higher educated people are more likely to move over longer distances than lower educated people. The variable measuring socio-economic position shows that all socio-economic groups (except service workers) are less likely to move over a longer distance than those with a professional or managerial position. This clearly shows that long distance mobility is an important instrument for the higher social classes to adjust their labour market position. Again we find that families are less likely to move than couples without children and singles. In the models of long distance mobility we find significant effects of region on the probability to move. Especially those living in the South-East, North-West, Catalunya and the Canary Islands are less likely than others to move over longer distances. With increasing house prices the probability to move over longer distances decreases significantly.

$$
\text { ***Table } 4 \text { around here }{ }^{* * *}
$$

To get more insight in the relationship between regional unemployment levels and long distance mobility, Tables 5 and 6 show matrices with long distance mobility for origin-destinations by unemployment rate quintiles for the years 2001 and 2011 respectively. The tables show how complex this relationship is. For both years the regions in the fifth unemployment quintile (the highest unemployment levels) both send and receive people over longer distances. So economic circumstances are not a simple explanation for the direction of mobility flows in $21^{\text {st }}$ century Spain. There are however some noteworthy temporal effects that can be mentioned. Shorrocks indexes show that socio-spatial immobility (mobility between the same quintiles, the diagonal) is more pronounced in 2011 than in 2001; implying that in 2011 people are more likely than in 2001 to move between similar distressed regions. The Bartholomew indexes also highlight an interesting fact; in 2001, mobility to regions with higher levels of unemployment was more important than mobility to regions with lower levels of unemployment, and in 2011 it was the other way around. So compared to 2001, in 2011 people were more likely to move to regions with more employment opportunities, which can be explained by the fact that in times of crisis people tend to move to less economically vulnerable regions. So patterns of socio-spatial mobility are affected by context, but more research is needed to understand the motives of movers and the role of structural conditions. 


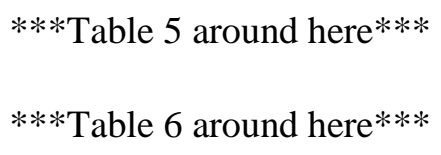

Interactions of homeownership and local unemployment level between 2001 and 2011

Our forth research question is to what extent homeownership is connected to the regional unemployment level in explaining mobility decisions in 2001 and 2011. This is a complicated question, but we have found some interesting evidences of their relationship and how it changed during the period of economic recession. Figure 3 graphically shows the Average Marginal Effects (AME's) of homeowners (compared to renters) probability to stay versus moving long and short distance over five regional unemployment quintiles in 2001 and 2011 (Table of Margins, SE, and Interval of confidence are shown in the Appendix, Table A.1 and A.2). Analysing Figure 3 confirms the results from our previous analyses: being a homeowner is much more associated with the probability to stay in 2011 compared to 2001, in all quintiles of unemployment and for both long and short distance mobility.

$* * *$ Figure 3 around here $* * *$

It is worth noting that homeownership and regional unemployment rate have a clearer relationship in 2011 than in 2001. In 2011 homeowners are more likely to stay in regions with a higher level of unemployment. An exception are regions with the lowest levels of unemployment, as people are also relatively likely to stay in these regions. The otherwise increasing probability to stay in regions with higher levels of unemployment is probably connected with economic vulnerability and insecurity. In areas with high unemployment some people are trapped in their owner-occupied dwellings because they cannot afford to move or to sell their dwelling.

\section{Discussion and conclusions}

The 2008 economic crisis has strongly affected the Spanish economy and society. Where other studies have focused mainly on the effects of the economic crisis on migration flows from abroad, this paper aimed to understand the effects of the crisis on both residential mobility and migration within Spain. Like in other Western countries, the crisis has led to a major decrease of spatial mobility (Aalbers, 2009), but the magnitude of the drop in mobility is especially pronounced for Spain. In the years before the economic crisis, spatial mobility was on the rise in Spain, but compared to 2001, in 2011 staying put became the norm, although with large differences between regions. The underlying mechanisms of the drop in spatial mobility are clearly connected to the economic crisis, but also have roots in much earlier structural developments in the Spanish economy and the housing market, especially the high level of homeownership.

The regional unemployment level is often seen as a predictor of migration between regions. In the Spanish context regional levels of unemployment seem to have a mixed effect on mobility. Compared to 2001, in 2011 unemployment levels seem to have a more pronounced effect on short distance mobility decisions; in 2011 people are less likely to move within regions with high levels of unemployment compared to 2001. Regarding long distance migration, we found that opposed to what is predicted by economic theory, vulnerable regional labour markets do not play a different role in understanding mobility in 2011 compared to before the crisis. Possible explanations for this finding are the complex geography of the Spanish labour market (Polavieja, 2006), or the fact that some regions which are strongly impacted by rising unemployment are also seen as attractive regions to live in (for example Andalucía). It might also be the case that because of high levels of unemployment in the whole of Spain, people do not perceive benefits of moving to other regions. This all does not mean that there is no relationship between regional labour market vulnerabilities and migration. In fact, we found a clear relationship between regional labour markets and spatial mobility. Compared to 2001, in 2011 
people were more likely to stay put, but those who migrated, moved to regions with more favorable labour markets. To better understand the underlying decision making processes of households, more targeted research is needed which investigates the impact of changing regional labour markets on mobility using a variety of spatial scales.

A second focal point of this paper was the effect of homeownership on residential mobility and migration in Spain. As could be expected in a country of homeowners, we found that with increasing economic vulnerability of the labour market, homeownership became an even more important factor in understanding both short and long distance mobility than before the crisis. We already knew that homeowners are less likely to move than renters because owning a home is bonding people with places for a variety of reasons, but the fact that homeownership is much more relevant in regions with high levels of unemployment in 2011 compared to 2001 means that the role of homeownership is also connected to regional disadvantage. As shown in previous research, during the crisis especially the lower social classes were affected in both their housing and labour careers, and especially when paying a mortgage homeowners may become trapped in their dwellings (García-Lamarca and Kaika, 2016). But homeownership could also act as a financial buffer in times of crisis, and function as a resource when other resources are scarce. The immobilizing effect of homeownership is also connected with local family and social networks, which especially for the lower social classes, are an important source of support in times of economic uncertainty. The relationship between homeownership and regional labour markets should be investigated in more detail. Where most of the current housing market research in Spain is focusing on the rising importance of the rental market, our findings suggest that more research is needed on the complex relationship between social class and homeownership, especially for the more vulnerable socio-economic groups.

\section{Acknowledgements}

This work was supported by the FPU program and the FPU research stays program, code AP-2012-2340. The paper presents some results of the research project 'Procesos de reconfiguración social metropolitana', funded by a Ministerio de Educación y Cultura grant, code CSO2014-55780-C3-3-P.

\section{References}

Aaalbers, M. B. (2009) Geographies of the Financial Crisis, Area 41(1), 34-42.

Alperovich, G., Bergsman, J., \& Ehemann, C. (1977). An econometric model of migration between US metropolitan areas, Urban Studies, 14(2), 135-145.

Antolín, P., \& Bover, O. (1993). Regional migration in Spain: the effect of personal characteristics and of unemployment, wage and house price differentials using pooled cross-sections. Madrid: Banco de España.

Aramburu, M. (2015). Rental as A Taste of Freedom: The Decline of Home Ownership amongst Working-class Youth in Spain during Times of Crisis, International Journal of Urban and Regional Research, 39(6), 1172-1190.

Artal, A., Navarro, J. \& Requena, F. (2015). Las migraciones interiores en España durante la crisis económica, in Anuario de la inmigración en España 2014, CIDOB, pp. 148-168.

Bähr, S. \& Abraham, A. (2016). The role of social capital in the job-related regional mobility decisions of unemployed individuals, Social Networks, 46, 44-59.

Ballard K P, Clark G L. (1981). The short run dynamics of interstate migration: a space - time economic adjustment model of in-migration to fast-growing states, Regional Studies, 15, 213- 228.

Bartel, A. (1979). The migration decision: what role does job mobility play?, American Economic Review, 69, 775-786.

Bartholomew, D. J. (1973). Stochastic Models for Social Process, London: John Wiley and Sons. 
Bentolila, S., \& Dolado, J. J. (1990). Mismatch and internal migration in Spain, 1962-1986 (No. 9006). Madrid: Banco de España, Servicio de Estudios.

Beyers, W. B. (1980). Migration and the development of multiregional economic systems, Economic Geography, 56, 320-334.

Bonnar, D. (1979) Migration in the southwest of England: an analysis of the interrelationship of housing, socio-economic status and labor demand, Regional Studies, 13, 345-359.

Cabré, A.C. \& Módenes, J.A. (2004). Home ownership and social inequality in Spain. In Kurz, K. (ed). Home ownership and social inequality in a comparative perspective. Stanford: Stanford University Press, pp. 233-254.

Campbell, K. E., Marsden, P. V. \& Hurlbert, J. S. (1986). Social resources and socioeconomic status, Social Networks, 8, 97-117.

Chen, Y. \& Rosenthal, S. S. (2008). Local amenities and life-cycle migration: Do people move for jobs or fun?, Journal of Urban Economics 64(3), 519-537.

Clark, G. L. \& Ballard, K. P. (1980). Modeling out-migration from depressed regions: the significance of origin and destination characteristics, Environment and Planning A, 12, 799-8 12.

Clark, W. A. (1982). Recent research on migration and mobility: a review and interpretation, Progress in planning, 18, 1-56.

Clark, W.A.V., \& Dieleman, F. M. (1996). Households and housing. Choice and outcomes in the housing market. New Jersey: Center for Urban Policy Research, New Brunswick.

Cleave, D. \& Cordey-Hayes, M. (1977). Migration dynamics and labour market turnover, Progress in Planning, 8, 1-95.

Conde, F. (2004). Urbanismo y ciudad en la aglomeración urbana de Granada. Sevilla. Consejería de Obras Pú-blicas y Transportes. Junta de Andalucía.

Cooke, T.J. (2008). Migration in a family way, Population, Space and Place, 14, 255-265.

Coulson, N. \& Fisher, L. (2002). Tenure choice and labour market outcomes, Housing Studies, $17(1), 35-49$.

Courchene, T. J. (1970). Interprovincial migration and economic adjustment, Canadian $J$ Economics, 3, 551-576.

Courgeau, D. (1988). Méthodes de mesure de la mobilité spatiale: migrations internes, mobilité temporaire et navettes, Population, 43(4/5), 877-880.

Cresswell, T. (2006). On the Move: Mobility in the Modern Western World. London: Routledge.

Crozet, M. (2004). Do migrants follow market potentials? An estimation of a new economic geography model, Journal of Economic Geography, 4(4), 439-458.

Dahl, M. S. \& Sorenson, O. (2010). The migration of technical workers, Journal of Urban Economics, 67(1) 33-45.

Dahlberg, A. \& Holmlund, B. (1978). The interaction of migration, income, and employment in Sweden, Demography, 15, 259-266.

DaVanzo, J. (1978) Does unemployment affect migration? Evidence on micro data, Review of Economics and Statistics, 60, 504-514.

Davanzo, J. (1981a). Microeconomic approaches to studying migration decisions. In G. F. De Jong, \& R. W. Gardner (Eds.), Migration decision making. Multidisciplinary approaches to microlevel studies in developed and developing countries, New York: Pergamon, pp. 90-129.

DaVanzo, J. (1981b). Repeat migration, information costs, and location-specific capital, Population and Environment 4(1) 45-73.

Davies S. \& Clark, W.A.V. (2006). Housing costs and the geography of family migration outcomes, Population, Space and Place, 12, 273-289.

Dawkins, C.J. (2006). Are social networks the ties that bind families to neighborhoods?, Housing Studies, 21, 867-888.

DiPasquale, D. \& Glaeser, E. (1999). Incentives and Social Capital: Are Homeowners Better Citizens?, Journal of Urban Economics, 45(2), 354-384. 
Dolado J ., Malo de Molina, J. \& Zabalza, A. (1986). Spanish Industrial Unemployment: Some Explanatory Factors, in C. Bean et al. (eds.) The Rise in Unemployment, London: Basil Blackwell, pp. 313-334.

Elhorst, J. P. (2003). The mystery of regional unemployment differentials: theoretical and empirical explanations, Journal of economic surveys, 17(5), 709-748.

Fields, G. S. (1976). Labor force migration, unemployment, and job turnover, Review of Economics and Statistics, 58, 407-415.

Fischer, P. A. and Malmberg, G. (2001). Settled people don't move: on life course and (im)mobility in Sweden, International Journal of Population Geography, 7, 357-371.

Fisher, P. A., \& Malmberg, G. (2001). Settled people don't move: On the life course and (im)mobility in Sweden, International Journal of Population Geography, 7, 357-371.

Fors, S. \& Lennartsson, C. (2008). Social mobility, geographical proximity and intergenerational family contact in Sweden, Ageing \& Society, 28, 253-270.

Garasky, S. (2002). Where are they going? A comparison of urban and rural youths' locational choices after leaving the parental home, Social Science Research, 31(3), 409-431.

García Coll, A., \& Stillwell, J. (1999). Inter-provincial migration in Spain: temporal trends and age-specific patterns, International Journal of Population Geography, 5(2), 97-115.

García-Lamarca, M., \& Kaika, M. (2016). 'Mortgaged lives': the biopolitics of debt and housing financialisation, Transactions of the Institute of British Geographers, 41(3), 313-327.

García-Lamarca, M., \& Kaika, M. (2016). 'Mortgaged lives': the biopolitics of debt and housing financialisation. Transactions of the Institute of British Geographers, 41(3), 313-327.

Ginsberg, R. (1971). Semi-markov processes and mobility, J. Mathematical Sociology, 1, 233262.

Graves, P.E. (1976). A Reexamination of Migration, Economic Opportunity and the Quality of Life, Journal of Regional Science 16(1), 107-112.

Greenwood, M. J. (1975). Research on Internal Migration in the United States: A Survey, Journal of Economic Literature, 8, 397-433.

Greenwood, M. J. (1985). Human Migration: Theory, Models and Empirical Studies, Journal of Regional Science, 25, 521-44.

Harris J. \& Todaro, M. (1970). Migration, Unemployment and Development: a Two-Sector Analysis, American Economic Review, 60, 126-142.

Helderman, A., Mulder, C. H., \& Van Ham, M. (2004). The changing effect of home ownership on residential mobility in the Netherlands, 1980-98, Housing Studies, 19, 601-616.

Hiscock, R., Kearns, A., Macintyre, S., \& Ellaway, A. (2001). Ontological security and psychosocial benefits from the home: Qualitative evidence on issues of tenure, Housing, Theory and Society, 18, 50-66.

Holdsworth, C, \& Irazoqui Solda, M. (2002). First Housing Moves in Spain: An Analysis of Leaving Home and First Housing Acquisition, European Journal of Population 18 (1), $1-19$.

Holland, J. A. (2012). Home and where the heart is: Marriage timing and joint home purchase, European Journal of Population/Revue européenne de Démographie, 28(1), 65-89.

Jimeno, J. F., \& Bentolila, S. (1998). Regional unemployment persistence (Spain, 1976-1994), Labour Economics, 5(1), 25-51.

Jones, G. (1999). 'The same people in the same places'? Socio-spatial identities and migration in youth. Sociology, 33(01), 001-022.

Kemmeny, J. (2001). Comparative Housing and Welfare: Theorising the Relationship, Journal of Housing and the Built Environment (16)1, 53-70.

Leal, J. (2004). El diferente modelo residencial de los países del sur de Europa: el mercado de viviendas, la familia y el Estado, Arxius de Sociologia, 10, 11-37.

Leal, J. (coord.) (2010). La política de vivienda en España. Madrid: Editorial Pablo Iglesias.

Litwak, E. \& Szelenyi, J. (1969). Primary group structures and their functions: kin, neighbours, and friends, American Sociological Review, 34, 465-481.

Liu, Y. \& Shen, J. (2013). Jobs or Amenities? Location Choices of Interprovincial Skilled Migrants in China, 2000-2005, Population, Space and Place 20(7), 592-605. 
McCormick, B. (1997). Regional unemployment and labour mobility in the UK, European Economic Review, 41(3), 581-589.

Módenes, J. A. (2004). Movilidad residencial, trabajo y vivienda en Europa. Scripta Nova: revista electrónica de geografía y ciencias sociales, 159. Available in: http://www.ub.edu/geocrit/sn/sn-159.htm.

Módenes, J. A. (2007). Una visión demográfica de la movilidad residencial reciente en España. In Feria, J.M. (coord.) La vivienda y el espacio residencial en las áreas metropolitanas, Sevilla: Centro de Estudios Andaluces, pp.15-33.

Módenes, J. A., Carro, C. F., \& Colás, J. L. (2013). La formación de hogares y la tenencia de vivienda de los jóvenes en la reconfiguración de los sistemas residenciales europeos, Scripta Nova: revista electrónica de geografía y ciencias sociales, 17, 425-462.

Módenes, J.A. \& López-Colás, J. (2014). Recent Demographic Change and Housing in Spain: Towards a New Housing System?, Revista Española de Investigaciones Sociológicas, 148, 103-134.

Mood C (2010). Logistic regression: Why we cannot do what we think we can do, and what we can do about it, European Sociological Review, 26, 67-82.

Moreno, A. (2016). Economic crisis and the new housing transitions of young people in Spain, International Journal of Housing Policy, 16(2), 165-183.

Morrison, P. \& Clark, W.A.V. (2011). Internal migration and employment: macro flows and micro motives, Environment and Planning A 43(10), 1948-1964.

Mulder, C. H. \& Cooke, T. J. (2009). Family ties and residential locations, Population, Space and Place, 15, 299-304.

Mulder, C.H. \& Malmberg G. (2014). Local ties and family migration, Environment and Planning A, 46, 2195-2211.

Mulder, C.H. \& Malmberg G. (2014). Local ties and family migration, Environment and Planning A, 46, 2195-2211.

Mulder, C.H. (2006). Home-ownership and family formation, Journal of Housing and the Built Environment, 21(3), 281-298.

Mulder, C.H., \& M. Wagner (1998). First-time home-ownership in the family life course: a West German-Dutch comparison, Urban Studies, 35(4), 687-713.

Niedomysl, T., \& Clark, W. A. (2014). What matters for internal migration, jobs or amenities?. Migration Letters, 11(3), 377.

Palomera, J. (2014). How did finance capital infiltrate the world of the urban poor? Homeownership and social fragmentation in a Spanish neighbourhood, International Journal of Urban and Regional Research, 38(1), 218-235.

Pareja-Eastaway, M. (2007). Residential opportunities and emancipation strategies in an owneroccupied dominated market, ACE: Arquitectura, Ciudad y Entorno, 5. Available on: http://hdl.handle.net/2099/3700.

Pissarides, C. A., \& McMaster, I. (1990). Regional migration, wages and unemployment: empirical evidence and implications for policy, Oxford Economic Papers, 42(4), 812831.

Polavieja, J.G. (2006) The incidence of temporary employment in advanced economies: why is Spain different?, European Sociological Review 22(1), 61-78.

Puga, D. (2004). El comportamiento residencial de los mayores. Análisis biográfico de la movilidad en la vejez, REIS, 105(1), 79-102.

Quigley, J. M. (2002). Transactions Costs and Housing Markets (Working Paper W02-005). Berkeley Program on Housing and Urban Policy.

Rant, K. E. \& Vanderkamp, J. (1980). The effects of migration on income: a macro study with Canadian data, 1965-7 1, Canadian J. Economics, 13, 381-406.

Rappaport, J. (2007). Moving to nice weather, Regional Science and Urban Economics 37(3): 375-398.

Reher, D. S. (1998). Family ties in Western Europe. Persistent contrasts, Population and Development Review, 24, 203-234. 
Ronald, R. (2008). The ideology of home ownership: Homeowner societies and the role of housing. UK: Palgrave Macmillan.

Shields, G. \& Shields, M. (1989). The Emergence of Migration Theory and a Suggested New Direction, Journal of Economic Surveys, 3, 277-304.

Shorrocks, A. F. (1978). The Measurement of Mobility, Econometrica, 46(5), 1013-1024.

Toribio, J. F. (2010). La delimitación y organización espacial de las áreas metropolitanas españolas: una perspectiva desde la movilidad residencia-trabajo. Ciudad y territorio, Estudios territoriales, 164-208.

Van Ham, M., \& Hooimeijer, P. (2009). Regional differences in spatial flexibility: long commutes and job related migration intentions in the Netherlands, Applied spatial analysis and policy, 2(2), 129-146.

Van Ham, M., Findlay, A., Manley, D., \& Feijten, P. (2012). Migration, occupational mobility, and regional escalators in Scotland, Urban Studies Research, doi:10.1155/2012/827171.

Van Ham, M., Mulder, C. H., \& Hooimeijer, P. (2001). Spatial flexibility in job mobility: macrolevel opportunities and microlevel restrictions, Environment and Planning A, 33(5), 921-940. 
Tables and figures

Table 1. Summary statistics

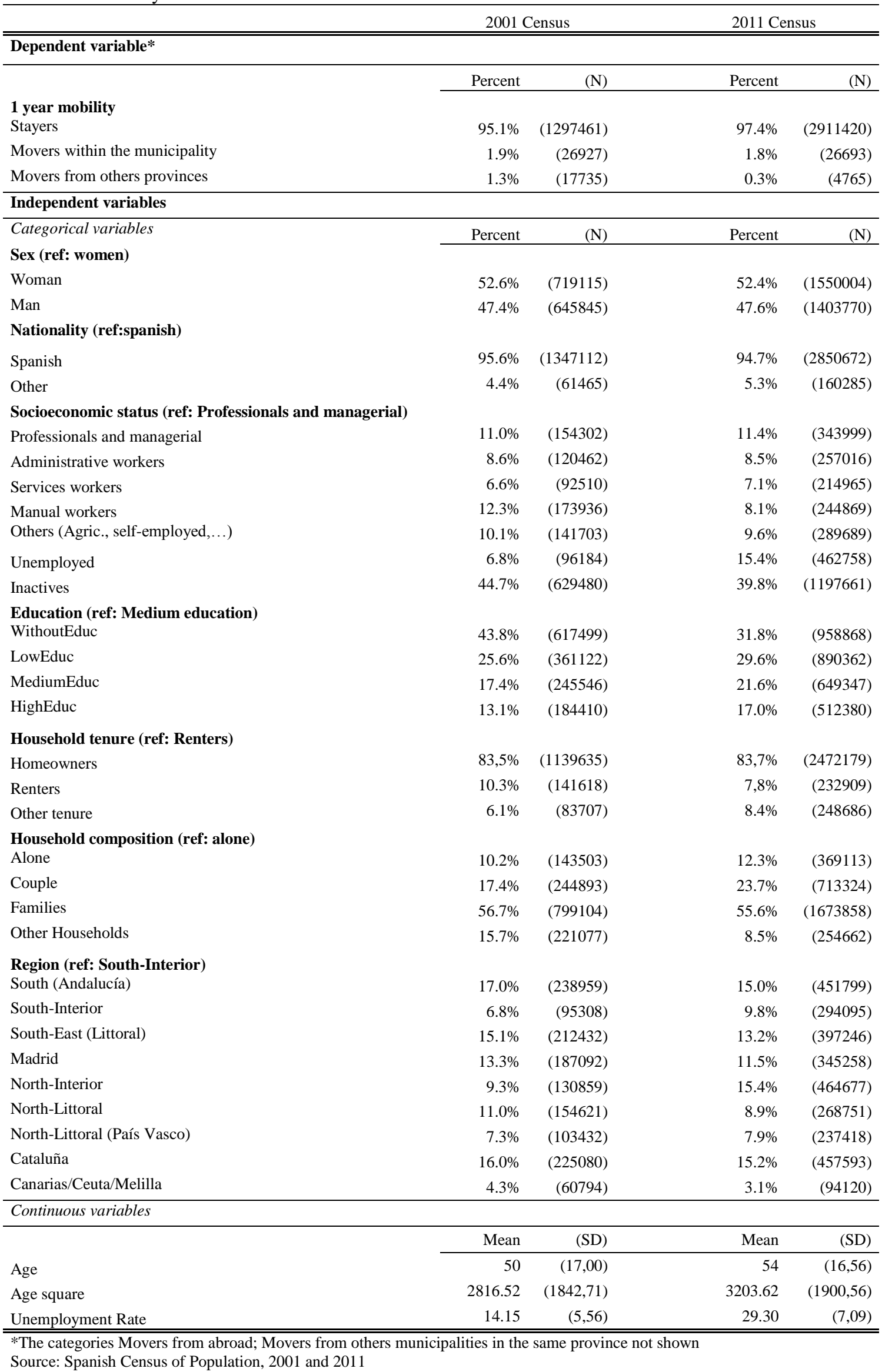


Figure 1. Unemployment rate and percentage of homeowners in 2001 and changes in \% points between 2001 and 2011
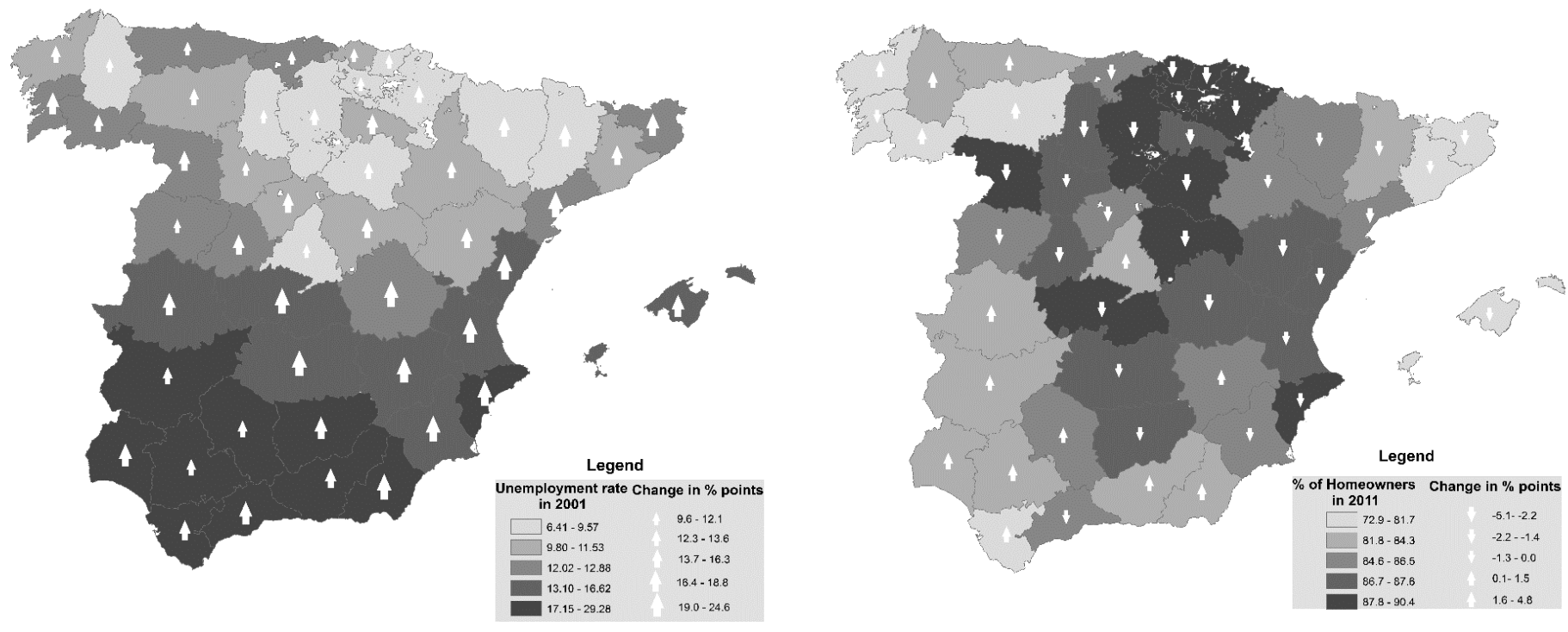

Source: Spanish Census of Population, 2001 and 2011

Table 2. Mobility rates by type of movements and census year $(\%)$

\begin{tabular}{lrrr}
\hline & & & Increment \\
& 2001 & 2011 & $2001-2011$ \\
\hline \hline Stayers & 95.05 & 97.39 & $\mathbf{2 . 4 7}$ \\
Within municipality & 1.97 & 1.83 & $\mathbf{- 7 . 2 7}$ \\
Within Province & 1.67 & 0.51 & $\mathbf{- 6 9 . 6 9}$ \\
Other Province & 1.31 & 0.27 & $\mathbf{- 7 9 . 0 7}$ \\
\hline Total mobility & 4.95 & 2.61 & -47.31 \\
\hline \hline
\end{tabular}

Source: Spanish Census of Population, 2001 and 2011 
Figure 2. Change in (im)mobility rates 2001-2011 by provinces (percent points). Sorted by Region and population size of prov.

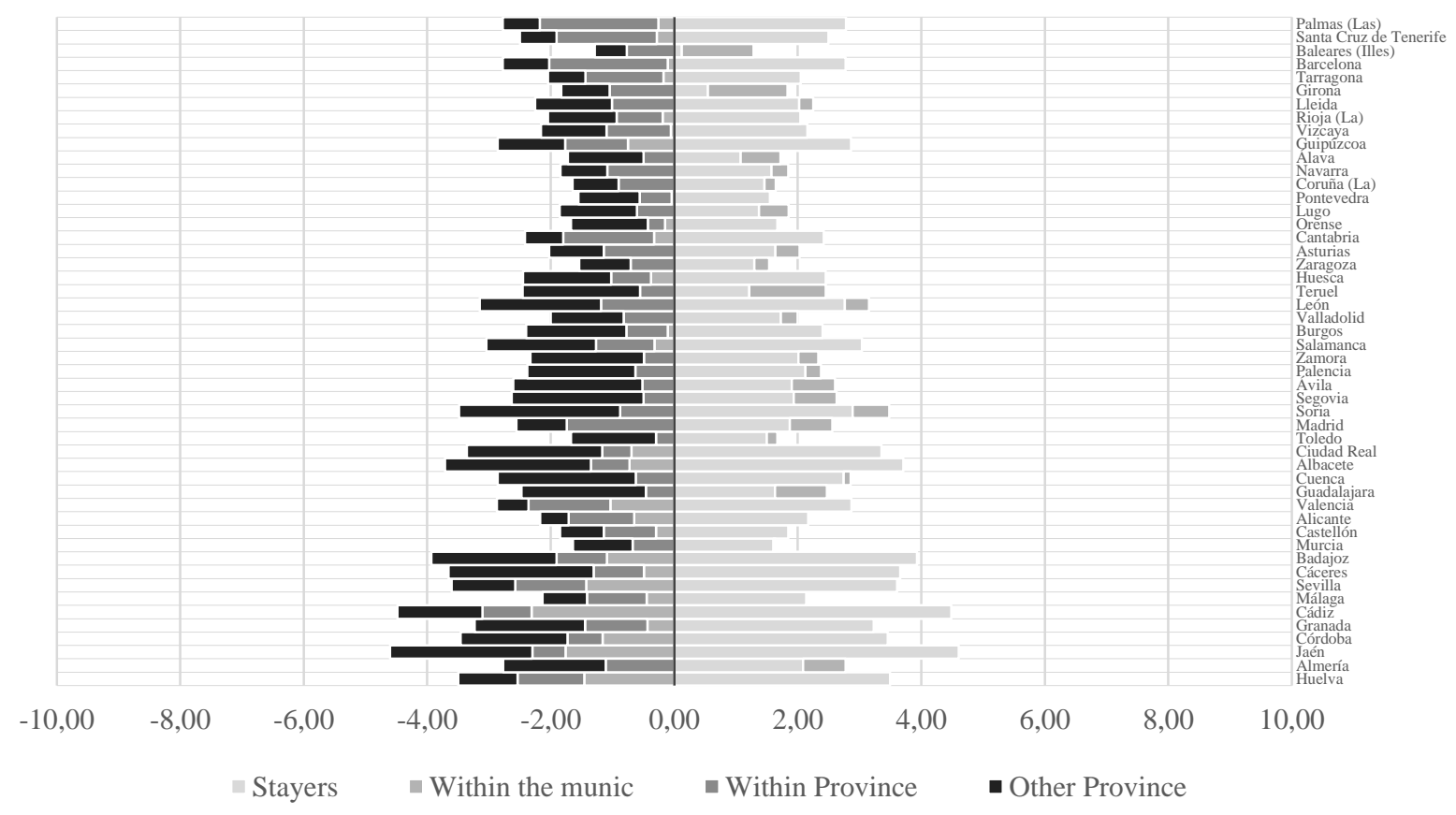

Source: Spanish Census of Population, 2001 and 2011 
Table 3. Logit model: short distance mobility in the last year

\begin{tabular}{|c|c|c|c|c|}
\hline & Model 1 & & Model 2 & \\
\hline & Coeff. & SE & Coeff. & SE \\
\hline \multicolumn{5}{|l|}{ Household tenure (ref: Renters ) } \\
\hline Homeowners & $-1.385^{* * *}$ & 0.130 & $-0.215^{* * *}$ & 0.055 \\
\hline Other tenure & $-1.193 * * *$ & 0.103 & $-0.165^{* *}$ & 0.056 \\
\hline Province Unemployment Rate $^{\wedge}$ & $0.301 *$ & 0.129 & $0.243^{*}$ & 0.107 \\
\hline Census Year (ref: 2001) & $-0.228 * * *$ & 0.063 & $1.603 * * *$ & 0.211 \\
\hline Age & $-0.128 * * *$ & 0.006 & $-0.129 * * *$ & 0.006 \\
\hline Age square & $0.001 * * *$ & 0.000 & $0.000 * * *$ & 0.000 \\
\hline Sex (ref: women) & $0.065 * * *$ & 0.008 & $0.062 * * *$ & 0.008 \\
\hline Nationality (ref:spanish) & $0.173 *$ & 0.069 & -0.023 & 0.084 \\
\hline \multicolumn{5}{|l|}{ Education (ref: Medium) } \\
\hline Any studies & $-0.127 * * *$ & 0.029 & $-0.120 * * *$ & 0.028 \\
\hline Low & -0.026 & 0.017 & -0.017 & 0.017 \\
\hline High & 0.024 & 0.019 & 0.022 & 0.019 \\
\hline \multicolumn{5}{|c|}{ Socioeconomic status (ref: Prof and manag.) } \\
\hline Administrative workers & 0.026 & 0.017 & 0.025 & 0.018 \\
\hline Services workers & 0.034 & 0.037 & 0.035 & 0.035 \\
\hline Manual workers & 0.032 & 0.024 & 0.036 & 0.023 \\
\hline Others (Agric., self-employed,...) & -0.039 & 0.026 & -0.034 & 0.025 \\
\hline Unemployed & $-0.058 * *$ & 0.018 & $-0.092 * * *$ & 0.019 \\
\hline Inactives & $-0.306^{* * *}$ & 0.029 & $-0.327 * * *$ & 0.031 \\
\hline \multicolumn{5}{|c|}{ Household composition (ref: Singles) } \\
\hline Couples & $0.152 * * *$ & 0.042 & 0.072 & 0.039 \\
\hline Families & $-0.727 * * *$ & 0.027 & $-0.786^{* * *}$ & 0.023 \\
\hline Others households & $-0.992 * * *$ & 0.055 & $-0.919 * * *$ & 0.040 \\
\hline \multicolumn{5}{|l|}{ Region (ref: South Interior) } \\
\hline South-Andalucía & 0.159 & 0.087 & $0.183^{*}$ & 0.073 \\
\hline South East & 0.151 & 0.101 & 0.120 & 0.087 \\
\hline Madrid & 0.118 & 0.179 & -0.083 & 0.131 \\
\hline North Interior & 0.098 & 0.092 & -0.030 & 0.088 \\
\hline NorthWest-Litoral & -0.002 & 0.093 & -0.106 & 0.088 \\
\hline North-Pais Vasco-Navarra & 0.219 & 0.122 & 0.013 & 0.125 \\
\hline Catalunya & -0.015 & 0.115 & -0.191 & 0.108 \\
\hline Canary Islands & -0.120 & 0.098 & -0.128 & 0.096 \\
\hline \multicolumn{5}{|l|}{ Provinces measures $^{\wedge}$} \\
\hline Housing prices & $-0.353^{* *}$ & 0.117 & $-0.256^{*}$ & 0.114 \\
\hline \multicolumn{5}{|l|}{ Interactions Household tenure } \\
\hline Year*Homeowners & & & $-2.025 * * *$ & 0.095 \\
\hline Year*Other tenure & & & $-1.657 * * *$ & 0.090 \\
\hline \multicolumn{5}{|l|}{ Interactions Unemployment rate } \\
\hline Year*Unemployment Rate & & & $-0.451 * *$ & 0.170 \\
\hline Constant & $1.763 * * *$ & 0.189 & $0.967 * * *$ & 0.190 \\
\hline $\mathbf{N}$ & 4.262 .501 & & 4.262 .501 & \\
\hline Log-Lik (Null) & -5612281.1 & & -5612281.1 & \\
\hline Log-Lik Full Model & -4773406.6 & & -4674751.6 & \\
\hline chi2 & 31662.8 & & 34905.8 & \\
\hline $\mathbf{R 2}$ & 0.149 & & 0.167 & \\
\hline AIC & 9546873.2 & & 9349569.3 & \\
\hline
\end{tabular}

$* \mathrm{p}<0.05, * * \mathrm{p}<0.01, * * * \mathrm{p}<0.001$

Source: Spanish Census of Population, 2001 and 2011 
Table 4. Logit model: long distance mobility in the last year (2001/2011)

\begin{tabular}{|c|c|c|c|c|}
\hline & \multicolumn{2}{|l|}{ Model 3} & \multicolumn{2}{|l|}{ Model 4} \\
\hline & Coeff. & SE & Coeff. & SE \\
\hline \multicolumn{5}{|l|}{ Household tenure (ref: Renters ) } \\
\hline Homeowners & $-1.561 * * *$ & 0.115 & $-1.281 * * *$ & 0.103 \\
\hline Other tenure & $-1.438 * * *$ & 0.136 & $-1.324 * * *$ & 0.159 \\
\hline Province Unemployment Rate ${ }^{\wedge}$ & -0.063 & 0.098 & -0.065 & 0.097 \\
\hline Census Year (ref: 2001) & $-1.720 * * *$ & 0.063 & $-1.282 * * *$ & 0.263 \\
\hline Age & $-0.067 * * *$ & 0.006 & $-0.068 * * *$ & 0.005 \\
\hline Age square & $0.001^{* * *}$ & 0.001 & $0.000 * * *$ & 0,001 \\
\hline Sex (ref: women) & $0.089 * * *$ & 0.016 & $0.087 * * *$ & 0.016 \\
\hline Nationality (ref:spanish) & -0.016 & 0.049 & $-0.129 * *$ & 0.044 \\
\hline \multicolumn{5}{|l|}{ Education (ref: Medium) } \\
\hline Any studies & $-0.331 * * *$ & 0.051 & $-0.330 * * *$ & 0.049 \\
\hline Low & $-0.217 * * *$ & 0.049 & $-0.208 * * *$ & 0.048 \\
\hline High & $0.323 * * *$ & 0.041 & $0.320 * * *$ & 0.041 \\
\hline \multicolumn{5}{|c|}{ Socioeconomic status (ref: Prof and manag.) } \\
\hline Administrative workers & $-0.212 * * *$ & 0.033 & $-0.210^{* * *}$ & 0.033 \\
\hline Services workers & -0.004 & 0.045 & -0.001 & 0.045 \\
\hline Manual workers & $-0.129 *$ & 0.064 & -0.121 & 0.064 \\
\hline Others (Agric., self-employed,...) & $-0.271 *$ & 0.109 & $-0.264^{*}$ & 0.108 \\
\hline Unemployed & 0.085 & 0.102 & 0.056 & 0.103 \\
\hline Inactives & -0.061 & 0.078 & -0.071 & 0.078 \\
\hline \multicolumn{5}{|l|}{ Household composition (ref: Singles) } \\
\hline Couples & 0.076 & 0.043 & 0.032 & 0.042 \\
\hline Families & $-0.869 * * *$ & 0.041 & $-0.900 * * *$ & 0.041 \\
\hline Others households & $-0.600 * * *$ & 0.068 & $-0.581 * * *$ & 0.065 \\
\hline \multicolumn{5}{|l|}{ Region (ref: South Interior) } \\
\hline South-Andalucía & $-0.255^{*}$ & 0.119 & $-0.255^{*}$ & 0.121 \\
\hline South East & $-0.970 * * *$ & 0.118 & $-0.963 * * *$ & 0.122 \\
\hline Madrid & $-0.376^{*}$ & 0.166 & $-0.364 *$ & 0.155 \\
\hline North Interior & -0.035 & 0.111 & -0.027 & 0.113 \\
\hline NorthWest-Litoral & $-0.610^{* * *}$ & 0.095 & $-0.604 * * *$ & 0.093 \\
\hline North-Pais Vasco-Navarra & -0.098 & 0.203 & -0.091 & 0.207 \\
\hline Catalunya & $-0.539 * * *$ & 0.15 & $-0.539 * * *$ & 0.148 \\
\hline Canary Islands & $-0.963^{* * *}$ & 0.11 & $-0.960 * * *$ & 0.086 \\
\hline \multicolumn{5}{|l|}{ Provinces measures $^{\wedge}$} \\
\hline Housing prices & $-0.801 * * *$ & 0.179 & $-0.793 * * *$ & 0.175 \\
\hline \multicolumn{5}{|l|}{ Interactions Household tenure } \\
\hline Year*Homeowners & & & $-1.461 * * *$ & 0.207 \\
\hline Year*Other tenure & & & -0.383 & 0.222 \\
\hline \multicolumn{5}{|l|}{ Interactions Unemployment rate } \\
\hline Year*Unemployment Rate & & & 0.223 & 0.279 \\
\hline Constant & $1.283 * * *$ & 0.232 & $1.136^{* * *}$ & 0.227 \\
\hline $\mathbf{N}$ & 4.231 .381 & & 4.231 .381 & \\
\hline Log-Lik (Null) & -2604638.2 & & -2604638.2 & \\
\hline Log-Lik Full Model & -2190567.8 & & -2175335.4 & \\
\hline chi2 & 9568.3 & & 14304.1 & \\
\hline $\mathbf{R 2}$ & 0.159 & & 0.165 & \\
\hline AIC & 4381195.5 & & 4350736.9 & \\
\hline
\end{tabular}

$* \mathrm{p}<0.05, * * \mathrm{p}<0.01, * * * \mathrm{p}<0.001$

Source: Spanish Census of Population, 2001 and 2011 
Table 5. Long distance movers in 2001 by unemployment rate quintiles origin/destination)

\begin{tabular}{|c|c|c|c|c|c|c|}
\hline Destinat. & $\begin{array}{r}1 \\
\text { Low Unem. }\end{array}$ & 2 & 3 & 4 & $\begin{array}{r}5 \\
\text { High Unem. }\end{array}$ & Total \\
\hline 1 Low Unem. & 14.43 & 37.93 & 25.16 & 11.24 & 11.24 & 100 \\
\hline 2 & 26.55 & 14.04 & 34.51 & 11.37 & 13.54 & 100 \\
\hline 3 & 8.91 & 25.34 & 28.29 & 18.47 & 18.98 & 100 \\
\hline 4 & 8.10 & 18.17 & 42.62 & 15.73 & 15.38 & 100 \\
\hline 5 High Unem. & 9.03 & 18.94 & 28.08 & 12.77 & 31.18 & 100 \\
\hline Total & 13.12 & 21.36 & 31.60 & 14.33 & 19.59 & 100 \\
\hline
\end{tabular}

Shorrrocks Index (movers): 0,961

Barthtolomew Index (Low Unem-High Unem): 67,32

Barthtolomew Index (High Unem-Low Unem): 66,97

Table 6. Long distance movers in 2011 by unemployment rate quintiles (origin/destination)

\begin{tabular}{|c|c|c|c|c|c|c|}
\hline $\begin{array}{l}\text { Destinat. } \\
\text { Origin }\end{array}$ & $\begin{array}{r}1 \\
\text { Low Unem. }\end{array}$ & 2 & 3 & 4 & $\begin{array}{r}5 \\
\text { High Unem. }\end{array}$ & Total \\
\hline 1 Low Unem. & 14.95 & 28.35 & 16.50 & 28.97 & 11.23 & 100 \\
\hline 2 & 32.13 & 17.09 & 28.78 & 12.26 & 9.73 & 100 \\
\hline 3 & 23.80 & 37.33 & 17.64 & 13.87 & 7.36 & 100 \\
\hline 4 & 24.04 & 17.87 & 13.88 & 25.71 & 18.51 & 100 \\
\hline 5 High Unem. & 17.89 & 13.39 & 7.65 & 20.92 & 40.16 & 100 \\
\hline Total & 22.48 & 22.06 & 17.71 & 20.80 & 16.96 & 100 \\
\hline
\end{tabular}

Shorrrocks Index (movers): 0,991

Barthtolomew Index (Low Unem-High Unem): 64,55

Barthtolomew Index (High Unem-Low Unem): 77, 34 
Figure 3. Average Marginal effects of homeowners on the probability to stay over Unemployment rate quintiles in 2001 and 2011

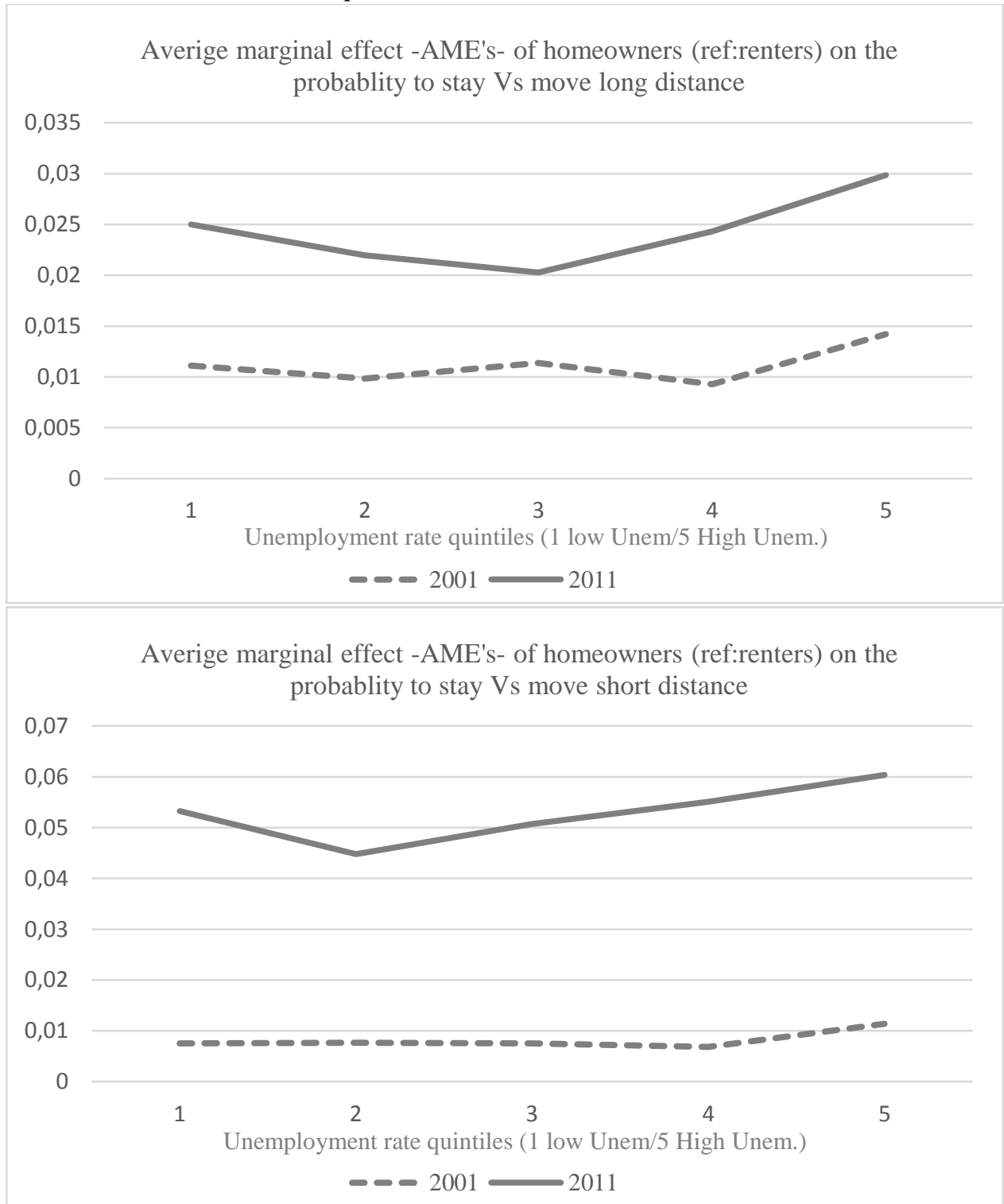

Source: Spanish Census of Population, 2001 and 2011 


\section{Appendix}

Table A.1. AME's of homeowners in the probability to stay VS move long distance*

\begin{tabular}{|c|c|c|c|c|c|c|c|c|}
\hline & \multicolumn{4}{|c|}{2001} & \multicolumn{4}{|c|}{2011} \\
\hline & $\mathrm{dy} / \mathrm{dx}$ & SE & \multicolumn{2}{|c|}{$95 \%$ Conf. Interval } & $\mathrm{dy} / \mathrm{dx}$ & SE & \multicolumn{2}{|c|}{$95 \%$ Conf. Interval } \\
\hline \multicolumn{9}{|c|}{ Unem. Quintiles } \\
\hline 1 Low Unem. & 0.011 & 0.000 & 0.010 & 0.012 & 0.025 & 0.001 & 0.024 & 0.026 \\
\hline 2 & 0.010 & 0.000 & 0.009 & 0.011 & 0.022 & 0.001 & 0.021 & 0.023 \\
\hline 3 & 0.011 & 0.001 & 0.010 & 0.013 & 0.020 & 0.000 & 0.019 & 0.021 \\
\hline 4 & 0.009 & 0.001 & 0.008 & 0.010 & 0.024 & 0.001 & 0.023 & 0.026 \\
\hline 5 High Unem. & 0.014 & 0.001 & 0.013 & 0.016 & 0.030 & 0.001 & 0.028 & 0.031 \\
\hline
\end{tabular}

*All margins are significant at $p<0.001$

Table A.2. AME's of homeowners in the probability to stay VS move short distance*

\begin{tabular}{|c|c|c|c|c|c|c|c|c|}
\hline & \multicolumn{4}{|c|}{2001} & \multicolumn{4}{|c|}{2011} \\
\hline & $\mathrm{dy} / \mathrm{dx}$ & SE & \multicolumn{2}{|c|}{$95 \%$ Conf. Interval } & $\mathrm{dy} / \mathrm{dx}$ & SE & \multicolumn{2}{|c|}{$95 \%$ Conf. Interval } \\
\hline \multicolumn{9}{|c|}{ Unem. Quintiles } \\
\hline 1 Low Unem. & 0.008 & 0.000 & 0.007 & 0.008 & 0.053 & 0.001 & 0.051 & 0.055 \\
\hline 2 & 0.008 & 0.000 & 0.007 & 0.008 & 0.045 & 0.001 & 0.043 & 0.046 \\
\hline 3 & 0.008 & 0.000 & 0.007 & 0.008 & 0.051 & 0.001 & 0.048 & 0.053 \\
\hline 4 & 0.007 & 0.000 & 0.006 & 0.008 & 0.055 & 0.001 & 0.053 & 0.057 \\
\hline 5 High Unem. & 0.011 & 0.001 & 0.010 & 0.013 & 0.060 & 0.001 & 0.058 & 0.063 \\
\hline
\end{tabular}

*All margins are significant at $\mathrm{p}<0.001$ 